\title{
Technical Note: New methodology for measuring viscosities in small volumes characteristic of environmental chamber particle samples
}

\author{
L. Renbaum-Wolff, J. W. Grayson, and A. K. Bertram \\ Department of Chemistry, University of British Columbia, 2036 Main Mall, Vancouver, BC, V6T 1Z1, Canada
}

Correspondence to: A. K. Bertram (bertram@chem.ubc.ca)

Received: 6 September 2012 - Published in Atmos. Chem. Phys. Discuss.: 15 October 2012

Revised: 3 January 2013 - Accepted: 10 January 2013 - Published: 22 January 2013

\begin{abstract}
Herein, a method for the determination of viscosities of small sample volumes is introduced, with important implications for the viscosity determination of particle samples from environmental chambers (used to simulate atmospheric conditions). The amount of sample needed is $<1 \mu \mathrm{l}$, and the technique is capable of determining viscosities $(\eta)$ ranging between $10^{-3}$ and $10^{3}$ Pascal seconds (Pa s) in samples that cover a range of chemical properties and with real-time relative humidity and temperature control; hence, the technique should be well-suited for determining the viscosities, under atmospherically relevant conditions, of particles collected from environmental chambers. In this technique, supermicron particles are first deposited on an inert hydrophobic substrate. Then, insoluble beads $(\sim 1 \mu \mathrm{m}$ in diameter) are embedded in the particles. Next, a flow of gas is introduced over the particles, which generates a shear stress on the particle surfaces. The sample responds to this shear stress by generating internal circulations, which are quantified with an optical microscope by monitoring the movement of the beads. The rate of internal circulation is shown to be a function of particle viscosity but independent of the particle material for a wide range of organic and organic-water samples. A calibration curve is constructed from the experimental data that relates the rate of internal circulation to particle viscosity, and this calibration curve is successfully used to predict viscosities in multicomponent organic mixtures.
\end{abstract}

\section{Introduction}

Atmospheric particles may play an important role in the Earth's climate by scattering and absorbing solar and terrestrial radiation and by acting as ice and liquid cloud droplet nuclei (IPCC, 2007). These particles may also influence atmospheric chemistry through heterogeneous interactions between particles and gas-phase compounds (Pöschl, 2005; George and Abbatt, 2010; Rudich et al., 2007). Despite their importance, many of their fundamental properties, including basic physical properties such as their phases and viscosities, remain poorly understood (Pöschl, 2005; Hallquist et al., 2009; Kanakidou et al., 2005; Vaden et al., 2011; Virtanen et al., 2010; Saukko et al., 2012). However, the particle viscosity can influence the ability of these particles to act as ice or liquid cloud droplet nuclei, uptake water and non-reactive gases, and undergo reactions with atmospheric oxidants (Zobrist et al., 2008, 2011; Renbaum and Smith, 2009; Murray, 2008; Murray et al., 2010, 2012; Vaden et al., 2011; Katrib et al., 2005; Mikhailov et al., 2009; Shiraiwa et al., 2011; Bones et al., 2012; Knopf et al., 2005; Virtanen et al., 2010; Wang et al., 2012). Likewise, the formation and growth of secondary organic aerosol (SOA) particles may be influenced by particle viscosity (Cappa and Wilson, 2011; Koop et al., 2011; Perraud et al., 2012; Shiraiwa et al., 2011; Vaden et al., 2011). In order to accurately predict the role of atmospheric particles in various atmospheric processes, the particle viscosities under various relative humidity $(\mathrm{RH})$ and temperature conditions should be known; yet, to date, no direct measurements of these viscosities have been made. Atmospheric particles may potentially vary from liquids, which typically have viscosities ranging from $10^{-3}-10^{2}$ Pas, to solids, which typically have viscosities $\geq 10^{12} \mathrm{Pas}$, as the water content and chemical composition of the particles vary. Additionally, sample volumes of particles that can be collected from the atmosphere or environmental chambers (which are used to simulate atmospheric conditions) are on the order of microliters (which 
corresponds to milligrams) assuming reasonable collection times (You et al., 2012). Hence a technique is required that can measure viscosities in small volumes $(\leq 1 \mu \mathrm{l})$ and over a wide range of viscosities.

While many viscometers are able to accommodate small sample volumes $(0.6-10 \mu \mathrm{l})$, they may not be well suited to studying many atmospherically relevant samples since they are limited to viscosities $<1 \times 10^{-1} \mathrm{Pas}$ (Han et al., 2007; Lin et al., 2007; Pipe and McKinley, 2009; Srivastava et al., 2005; Srivastava and Burns, 2006; Silber-Li et al., 2004). Atomic force microscopy can also be used to determine viscosities in small $(\leq 200 \mu \mathrm{l})$ samples, but is also limited to low viscosities $\left(<5 \times 10^{-2} \mathrm{Pas}\right)$ due to the strong dissipative effects which exist at higher viscosities (Ahmed et al., 2001; Bergaud and Nicu, 2000). Various fluorescence microscopy techniques can be used to determine diffusion constants in samples as small as single cells (Hess et al., 2002; Reits and Neefjes, 2001; Rossow et al., 2010; Spiller et al., 2010), and the viscosities of the samples may then be estimated with some foreknowledge of the hydrodynamic radius of the fluorescent dye. Fluorescence recovery after photobleaching, which allows the highest viscosity measurements of these techniques, is typically limited to viscosities $<10 \mathrm{Pas}$ (this limit was calculated assuming a hydrodynamic radius of $\sim 1 \mathrm{~nm}$ for the fluorescent dye (Nagy et al., 1989) and a data collection time of $10 \mathrm{~min}$ ). In addition to being limited to relatively low viscosities, fluorescence microscopy techniques require specialized equipment that is not available in many laboratories.

A viscosity-dependent phenomenon in the area of cloud microphysics that has received significant attention in the past is the internal circulation within a water droplet as it falls through air. Internal circulations develop due to the flow of the gas past the drop surface, which imposes shear stress on the drop (LeClair et al., 1972). Consistent with experiments (Abdel-Alim and Hamielec, 1975; LeClair et al., 1972; Pruppacher and Beard, 1970; Szakáll et al., 2009; Garner and Haycock, 1959), theory predicts that the internal circulation flow patterns resemble circular vortices (Hadamard, 1911; LeClair et al., 1972). A two dimensional representation of the flow patterns predicted by theory are illustrated in Fig. 1 (Hadamard, 1911; LeClair et al., 1972). In three dimensions the circulation should envelop a circle of radius $r=a / \sqrt{2}$ that lies in a plane perpendicular to the image in Fig. 1, where $a$ is the radius of the falling droplet. Theory (Spells, 1952; Hadamard, 1911) also predicts that the rate of internal circulations within the droplets will depend on the viscosity of the drop - as the viscosity increases the circulation will decrease (Hadamard, 1911; LeClair et al., 1972; McDonald, 1954).

Here, we outline a simple technique for measuring viscosities that is based in part on the phenomenon described above (i.e. internal circulation in a particle due to a shear stress by a gas) and show that the technique may be applied to measure the viscosity of multicomponent, complex mixtures. Supermicron particles of the sample material are first

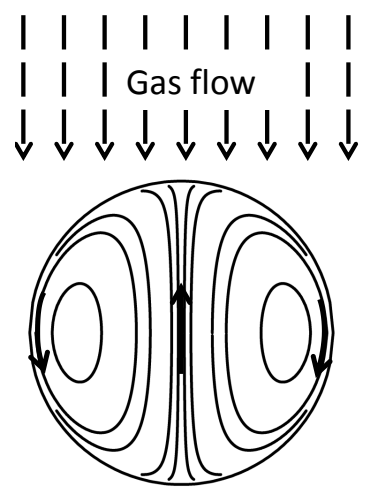

Fig. 1. 2-Dimensional representation (cross-sectional view though the center of the drop and parallel with the gas flow) of the theoretical internal flow patterns for a liquid spherical drop as it falls at terminal velocity through a stationary fluid (Hadamard, 1911; LeClair et al., 1972). The dashed arrows represent the direction of the gas flow and the solid arrows represent the direction of the internal flow (i.e. streamlines). The 3-dimensional flow is axisymmetric about an axis directed towards the pole of the sphere along which the gas moves.

deposited on an inert hydrophobic substrate. Then insoluble beads ( $\sim 1 \mu \mathrm{m}$ in diameter) are embedded in the supermicron particles. Next a flow of gas is introduced over the particles, which generates a shear stress on the particle surfaces (Fig. 2a). The sample responds to this shear stress by generating internal circulations, the speed of which is quantified with an optical microscope by monitoring the movement of the beads (Fig. 2b). The rate of internal circulation is related to the gas flow rate and the viscosity of the particles. It follows that at a given gas flow rate, the rate of internal circulation can be related to the particle viscosity. Since viscosity is not particle size dependent except under very atypical circumstances (Malik et al., 2010) the results obtained with this technique should be applicable to particles at least as small as $0.1 \mu \mathrm{m}$.

The amount of sample needed to prepare the supermicron particles using the technique described herein is $<1 \mu$ l. In practice, only one supermicron particle with a volume of $10 \mathrm{~s}$ of picoliters is needed for viscosity measurement although on the order of $\sim 1 \mathrm{mg}$ of sample is needed to generate the solutions from which particles are made using the techniques described here. In addition to the small sample volumes required, the technique allows viscosities ranging at least between $10^{-3}<\eta<10^{3}$ Pas to be measured in particles that cover a wide range of chemical properties characteristic of environmental chamber samples. Furthermore the technique requires instrumentation that is relatively inexpensive and is available in many laboratories and allows for real-time control over the relative humidity (or equilibrium water content) and temperature of the sample particles. Hence the technique is well suited for measuring viscosities in samples collected from environmental chambers under atmospherically relevant conditions. 


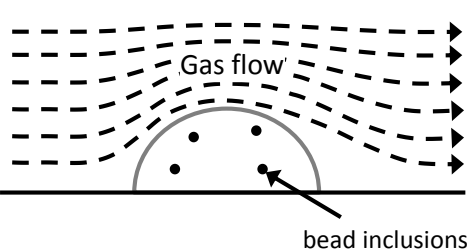

(a)

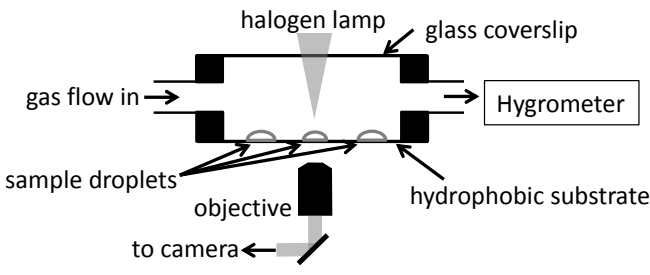

(b)

Fig. 2. (a) Illustration of flow around a sample particle. (b) Schematic of instrumental setup where the hydrophobic substrate was either siliconized glass or Teflon. The gas flow was $\mathrm{N}_{2}$, either introduced as a dry flow or as a humidified flow.

Table 1. Types of material studied as well as the molecular formula, molecular weight (MW), oxygen-to-carbon (O:C) atomic ratio and viscosity $\left(20^{\circ} \mathrm{C}\right)$ of the material. The materials have been arranged by increasing O:C ratio.

\begin{tabular}{|c|c|c|c|c|c|c|}
\hline Particle material & $\begin{array}{c}\text { Range of } \\
\text { concentrations } \\
\text { studied } \\
\text { (wt } \% \text { organic) }\end{array}$ & $\begin{array}{c}\text { Molecular formula of } \\
\text { organic }\end{array}$ & $\begin{array}{c}\text { MW of } \\
\text { organic } \\
\left(\mathrm{g} \mathrm{mol}^{-1}\right)\end{array}$ & $\begin{array}{l}\mathrm{O}: \mathrm{C} \text { of } \\
\text { organic }\end{array}$ & $\begin{array}{c}\text { Range of } \\
\text { viscosities } \\
\text { studied (Pas) }\end{array}$ & $\begin{array}{l}\text { References for } \\
\text { viscosities }\end{array}$ \\
\hline Oleic Acid & $\sim 100$ & $\mathrm{C}_{18} \mathrm{H}_{34} \mathrm{O}_{2}$ & 282 & 0.11 & 0.04 & $\begin{array}{l}\text { Noureddini et al. (1992); } \\
\text { Valeri and Meirelles (1997) }\end{array}$ \\
\hline Tergitol $^{\mathrm{TM}}$ NP-7 ${ }^{\mathrm{a}}$ & $\sim 100$ & $\mathrm{C}_{29} \mathrm{H}_{52} \mathrm{O}_{8}$ & 528 & 0.28 & $0.307^{\mathrm{b}}$ & Dow Chemical Company (2004) \\
\hline 1,2,6-hexanetriol & $\sim 100$ & $\mathrm{C}_{6} \mathrm{H}_{14} \mathrm{O}_{3}$ & 134 & 0.50 & 2.63 & Aldrich Chemical Company (1996) \\
\hline $\begin{array}{l}\text { Polyethylene } \\
\text { glycol- } 600\end{array}$ & $\sim 100$ & $\mathrm{H}\left(\mathrm{OCH}_{2} \mathrm{CH}_{2}\right)_{n} \mathrm{OH} n=12-14$ & $600^{c}$ & 0.54 & $0.17^{\mathrm{d}}$ & Zhang et al. (2011) \\
\hline $\begin{array}{l}\text { Polyethylene } \\
\text { glycol-400 }\end{array}$ & $\sim 100$ & $\mathrm{H}\left(\mathrm{OCH}_{2} \mathrm{CH}_{2}\right)_{n} \mathrm{OH} n=8-9$ & $400^{\mathrm{c}}$ & 0.56 & 0.134 & Heymes et al. (2006) \\
\hline $\begin{array}{l}\text { Polyethylene } \\
\text { glycol-300 }\end{array}$ & $\sim 100$ & $\mathrm{H}\left(\mathrm{OCH}_{2} \mathrm{CH}_{2}\right)_{n} \mathrm{OH} n=6-7$ & $300^{\mathrm{c}}$ & 0.58 & 0.075 & Heymes et al. (2006) \\
\hline $\begin{array}{l}\text { Tetraethylene } \\
\text { glycol }\end{array}$ & $\sim 100$ & $\mathrm{C}_{8} \mathrm{H}_{15} \mathrm{O}_{5}$ & 194 & 0.63 & 0.055 & $\begin{array}{l}\text { Dow Chemical Company (2007); } \\
\text { Moumen et al. (2006) }\end{array}$ \\
\hline Sucrose + Water & $55-84$ & $\mathrm{C}_{12} \mathrm{H}_{22} \mathrm{O}_{11}$ & 342 & 0.92 & $0.047-343$ & See Supplement \\
\hline $\begin{array}{l}\text { Glycerol + Water } \\
\left(20^{\circ} \mathrm{C} \text { data }\right)\end{array}$ & $35-\sim 100$ & $\mathrm{C}_{3} \mathrm{H}_{8} \mathrm{O}_{3}$ & 92 & 1.00 & $2.91 \times 10^{-3}-1.41$ & See Supplement \\
\hline $\begin{array}{l}\text { Glycerol + Water } \\
\left(0{ }^{\circ} \mathrm{C} \text { data }\right)\end{array}$ & $21-92$ & $\mathrm{C}_{3} \mathrm{H}_{8} \mathrm{O}_{3}$ & 92 & 1.00 & $3.63 \times 10^{-3}-1.89$ & See Supplement \\
\hline
\end{tabular}

a $\alpha$-(4-nonylphenyl)- $\omega$-hydroxy-poly(oxy-1,2-ethanediyl), branched. $>97 \mathrm{wt} \%$,

b Viscosities extrapolated from the cited literature viscosity data at $25^{\circ} \mathrm{C}$ to $20^{\circ} \mathrm{C}$ using the

temperature dependence for Tergitol ${ }^{\mathrm{TM}} \mathrm{NP}-7$ predicted by the Joback group contribution method,

c Average molecular weight,

${ }^{\mathrm{d}}$ Calculated based on polynomial fit to cited viscosity vs. temperature data between $25-50{ }^{\circ} \mathrm{C}$.

\section{Experimental}

\subsection{Types of particles studied}

For these experiments we focused on particles consisting of organics and mixtures of organics and water (i.e. aqueous organic solutions), since organics comprise a large fraction of atmospheric aerosol particles (Jimenez et al., 2009; Kanakidou et al., 2005). The specific organics (purchased from Sigma Aldrich in all cases with purities $\geq 99 \%$ unless otherwise noted) studied are listed in Table 1. Also included in Table 1 are the molecular formula, molecular weight (MW) and oxygen-to-carbon (O:C) atomic ratio of the organic material and the viscosities of the samples studied based on literature data. The specific species were chosen to cover the range of $\mathrm{O}: \mathrm{C}$ values and molecular weights expected for organic particles found in the atmosphere. As a large fraction of organic particles in the atmosphere are expected to be hygroscopic (i.e. take up water as the RH increases from 0 to $100 \%$ ), it was also important to study aqueous organic solutions. Aqueous solutions of glycerol and sucrose were chosen because these solutions cover a wide range of viscosities (nearly six orders of magnitude) and because they have wellestablished viscosity data in the literature across large concentration ranges $(0-100 \mathrm{wt} \%$ glycerol and $0-85 \mathrm{wt} \%$ sucrose).

All experiments were carried out at room temperature (which ranged from $20-21.5^{\circ} \mathrm{C}$ ), except for a set of experiments with glycerol-water solutions, which were carried out at both room temperature and $0{ }^{\circ} \mathrm{C}$. The $0{ }^{\circ} \mathrm{C}$ experiments were carried out to determine the effect of temperature on the relationship between internal circulation rate and particle viscosity. 
In addition to the species studied in Table 1, particles of virgin olive oil were also investigated using the technique described herein in to show that the technique is applicable to complex mixtures.

\subsection{Production of particles}

Dilute aqueous (or methanol in the cases of oleic acid and olive oil) solutions of the standards were prepared and nebulized to form supermicron particles on a hydrophobic glass or Teflon slide. A dilute aqueous suspension of $\sim 1 \mu \mathrm{m}$ hydrophilic melamine beads (actual diameter $\sim 930 \pm 50 \mathrm{~nm}$, Sigma Aldrich Cat\# 86296) was then nebulized over the slide containing the supermicron particles, which resulted in the beads being incorporated into the particle bulk. Melamine beads were chosen as they are prepared by the manufacturer without the use of surfactants and are not susceptible to swelling or aggregation in solution. The slide containing the sample particles with bead inclusions was then placed in a flow cell with relative humidity control (see Fig. 2b). All particles were between $30-50 \mu \mathrm{m}$ in diameter.

For particles studied in the absence of water, experiments were carried out with the relative humidity of the carrier gas set to $<0.5 \% \mathrm{RH}$. For particles consisting of aqueous organic solutions, $\mathrm{RH}$ values ranging from 25 to $95 \% \mathrm{RH}$ were used. To calculate the composition of the particles for a given $\mathrm{RH}$, relationships between $\mathrm{RH}$ and composition were used (for aqueous solutions of sucrose see Zobrist et al. (2011) and for aqueous solutions of glycerol see Table S1 in the Supplement).

\subsection{Viscosity of the particles}

In order to explore the relationship between internal circulation and particle viscosity, viscosities of the standards listed in Table 1 were needed. For the single component organics (at $<0.5 \% \mathrm{RH}$ ), viscosities were assumed to be well approximated by the viscosity of the pure organic and were taken from the references shown in Table 1, last column. For aqueous solutions of sucrose and glycerol, we used relationships between RH and viscosity developed in the Supplemental Information (see Table S2 in the Supplement) to calculate viscosity in the experiments. For the virgin olive oil samples we used a rotational viscometer (Haake RotoVisco 550) to determine the viscosity of the bulk sample (see Supplement).

\subsection{Microscopy/flow cell}

The flow cell is similar to those described in detail elsewhere (Bodsworth et al., 2010; Parsons et al., 2004) except the flow cell used herein had an internal volume of $0.1 \mathrm{~cm}^{3}$. Briefly, the slide is mounted in the flow cell where the relative humidity is controlled by using a water bubbler in a temperature-controlled bath. The flow of ultra-high purity nitrogen through the high purity water $(18 \mathrm{M} \Omega \mathrm{cm})$ is maintained at a constant flow rate (1.2 standard liters per minute, slpm, or $\sim 100 \mathrm{cms}^{-1}$ through the cell except in Sect. 3.3 where the effect of flow rate was explored) and the RH in the cell is adjusted by controlling the bath temperature. A hygrometer (General Eastern, Model 1311DR) in line after the flow cell was used to determine the dew point temperature of the flow and a thermocouple was used to determine the temperature of the sample cell, which was maintained at room temperature unless otherwise noted.

The Reynolds number for flow around the particle, $\mathrm{Re}_{\text {particle }}$, can be calculated by the equation $\mathrm{Re}_{\text {particle }}=$ $\left(\rho_{\mathrm{g}} U_{\mathrm{g}} d_{\mathrm{p}}\right) / \eta_{\mathrm{g}}$ where $U_{\mathrm{g}}$ is the speed of the gas far from the particle surface, $\rho_{\mathrm{g}}$ and $\eta_{\mathrm{g}}$ are the density and viscosity of the gas, and $d_{\mathrm{p}}$ is the particle diameter (Reist, 1984). Re $\mathrm{e}_{\text {particle }}$ was typically between $0.03-7$ across the flow rate range described in Sect. 3.3 and between 2-3 for the remainder of the experiments described herein. Thus the flow across the particles is at the upper limit of the laminar flow regime or the lower limit of the intermediate flow regime for a fluid flowing around a particle.

The flow cell was mounted to a light-transmitting microscope (63x objective, Zeiss Axio Observer) or reflectance microscope (50x objective, Zeiss Axiotech) and images were collected every $0.2-40 \mathrm{~s}$, depending on the rate of movement of the beads within the particles. During an experiment the frame rate was adjusted in order to observe measureable movement in each frame. Images were exported to ImageJ software and the average speed of bead movement in the $\mathrm{x}$ and $y$ directions was determined by observing the movement of 3-10 beads over 50-100 frames. The focus of the microscope was adjusted roughly to mid-height in the particle. At this height, it was possible to observe all beads within the particle, although some of the beads were outside the depth of focus of the microscope objective and thus were not in perfect focus. The beads also move in the $\mathrm{z}$ direction within the particle matrix, but since we are interested only in a correlation between viscosity and some measure of the speed of movement of the beads and because the $\mathrm{z}$ position is not finely resolvable in these experiments, we consider only bead movement in the $\mathrm{x}$ and $\mathrm{y}$ directions, which we refer to as bead speed.

In a separate experiment, by using confocal laser scanning microscopy with optics that allow the observation of the reflectance of light from the particle surface, the z-position of the air-particle interface was resolvable and in conjunction with transmission microscopy to monitor the bead location, we confirmed that the beads were not present at the air-particle interface. The absence of beads at the air-particle interface was expected since the melamine beads were manufactured with a hydrophilic coating and are thus not expected to be surface-active. Therefore, the movement of melamine beads in these experiments is due to the internal circulation and not circulation at the air-particle interface. 


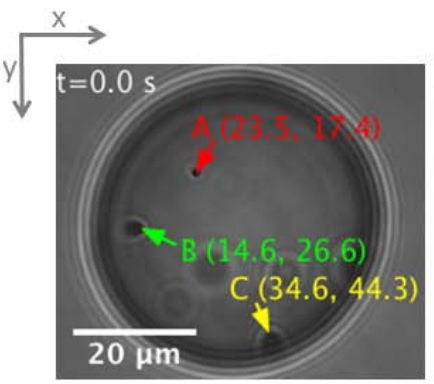

(a)

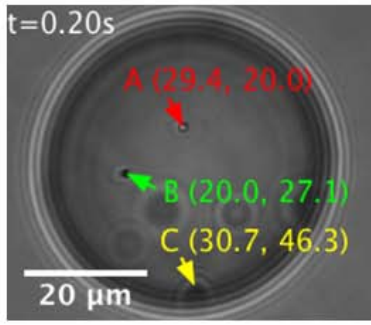

(b)

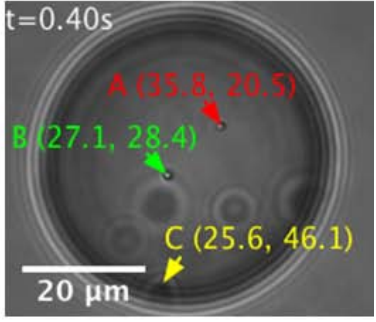

(c)

Fig. 3. Movement of beads "A" and "B" and "C" in an aqueous glycerol particle at $85 \% \mathrm{RH}(\mathbf{a}) t=0 \mathrm{~s}$, (b) $t=0.20 \mathrm{~s}$, and (c) $t=0.40 \mathrm{~s}$. The $\mathrm{x}$ and $\mathrm{y}$ coordinates of the beads are included in brackets. Four other circular spots are also evident in the droplets but not labeled. These unlabeled spots are due to either beads that are stuck on the substrate surface that do not move during the experiment or due to dust on the microscope optics. Immobile beads are not included in the data collection. The gas flow is in the direction of negative $\mathrm{x}$ values.

\subsection{Contact angles of particles on substrate}

Contact angles were determined by photographing a large particle ( $\sim 3-4 \mathrm{~mm}$ diameter) of the standard on the same substrate as used during the bead experiments and then measuring the contact angle using ImageJ software.

\section{Results and discussion}

\subsection{Example of data}

Shown in Fig. 3a-c is a glycerol particle at $\sim 85 \%$ RH under a shear flow of humidified $\mathrm{N}_{2}$ at a flow rate of $100 \mathrm{~cm} \mathrm{~s}^{-1}$. Shown in Movie S1 is the same glycerol particle over 90 frames. From Fig. 3a-c, one can determine that the beads are moving $4-7 \mu \mathrm{m}$ every $0.20 \mathrm{~s}$ in the $\mathrm{x}-\mathrm{y}$ plane.

The average speed of individual beads in a single particle vary by a factor of 2-4 depending at least in part on their location within the particle; however, by considering the average bead speed of several beads (3-10) in many particles (35) over 50-100 frames, an average is obtained and this average can be correlated to the particle viscosity (see Sect. 3.4). The average bead speed results are very reproducible from experiment to experiment (typically varying by a factor of two or less), suggesting that the flow fields around the particles are reproducible from experiment to experiment. For example, no significant difference (at $95 \%$ confidence) between average bead speeds measured on different days but with the same gas flow speed, relative humidity, temperature, and particle type was observed for the particle sizes used herein $(30-50 \mu \mathrm{m})$.

\subsection{Internal circulation patterns}

The internal circulation patterns in the $x-y$ plane can be roughly visualized by tracing the $2 \mathrm{D}$ projected path of the beads as they move over time. Between frames, the beads
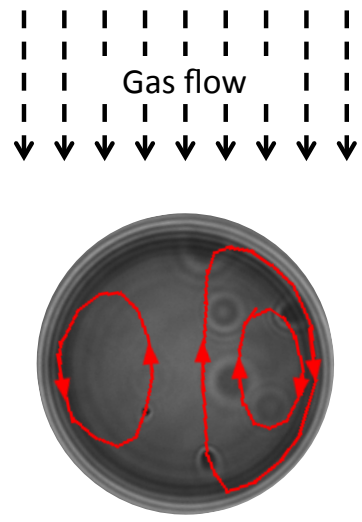

Fig. 4. Internal circulation patterns observed within a glycerol particle at $85 \% \mathrm{RH}$. The focus of the microscope was set at approximately half of the particle height, from which point all of the beads in the particle were visible and their $\mathrm{x}$ and $\mathrm{y}$ coordinates were determined. The red lines are the circulation patterns from monitoring three beads during one cycle of circulation within the particle where the circulation patterns are a 2-D projection of the bead movement in the $x-y$ plane. The circulation patterns have been overlaid on the particle image.

move from one location in the particle $\left(\mathrm{x}_{0}, \mathrm{y}_{0}\right)$ to another $\left(\mathrm{x}_{1}, \mathrm{y}_{1}\right)$ to another $\left(\mathrm{x}_{2}, \mathrm{y}_{2}\right)$, and so on, as observed in Fig. 3. By connecting these points with lines for one entire cycle of circulation, the circulation patterns in Fig. 4 were constructed. Similar to a particle falling through a gas (Fig. 1), vortices develop within the particles.

\subsection{Effect of gas flow rate}

Shown in Fig. 5 are the average bead speeds $( \pm 1 \sigma)$ within glycerol and aqueous glycerol particles (diameter $=30$ $50 \mu \mathrm{m})$. At a flow rate of $\sim 1 \mathrm{~cm} \mathrm{~s}^{-1}$, the bead movement was $<0.2 \mu \mathrm{m}$ in $10 \mathrm{~min}$ and thus the upper limit to the bead speed was $\sim 3 \times 10^{-7} \mu \mathrm{m} \mathrm{ms}^{-1}$ at this flow rate. 


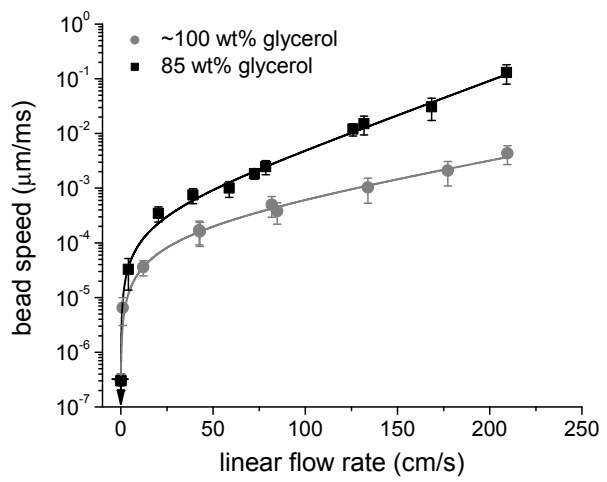

Fig. 5. Bead speed in glycerol particles vs. gas flow rate for $\sim 100 \mathrm{wt} \%$ glycerol and $85 \mathrm{wt} \%$ glycerol where the symbols represent the average bead speed and the error bars represent $1 \sigma$.

As discussed above the movement of the melamine beads inside the particle matrix was caused by the shear stress of the gas flow across the particle surface, which causes internal mixing within the particle. Increasing the shear stress by increasing the flow rate of the gas in turn causes an increase in the speed of mixing where the magnitude of the speed change depends on the particle viscosity (McDonald, 1954; Song et al., 2003). The shape of the curves in Fig. 5 are roughly consistent with the shape expected for a spherical droplet in an axisymmetric gas flow (McDonald, 1954; Song et al., 2003).

\subsection{Effect of particle viscosity}

In order to investigate the effect of particle viscosity on the speed of the beads, standards (Table 1) of known viscosity were tested under a constant linear gas flow rate of $100( \pm 5) \mathrm{cm} \mathrm{s}^{-1}$ and at room temperature $\left(20-21.5^{\circ} \mathrm{C}\right)$. As shown in Fig. 6a, bead speeds correlated well with the particle viscosity over the range of $10^{-3}<\eta<10^{3} \mathrm{Pas}$. The data were fit to a power function $s=a \times \eta^{b}$ where $s$ is the average bead speed in $\mu \mathrm{m} / \mathrm{ms}, \eta$ is the particle viscosity in Pas, and $a$ and $b$ are the best-fit parameters. The fit to this function gave a best fit $R^{2}=0.988$ with $a=2.73 \times 10^{-4}$ and $b=-0.955$. According to theory for a spherical particle moving through a gas under laminar flow conditions, the speed of internal circulation should be inversely proportional to the particle viscosity at a constant gas flow rate. Thus, if a power function, $s=a \times \eta^{b}$, is used to describe internal circulation within a spherical particle moving through a gas under laminar flow conditions, the theoretical value of the parameter $b$ should be -1 (Hadamard, 1911; LeClair et al., 1972; Milne-Thomson, 1968). The best fit parameter $b=-0.955$ for our experiments is very close to this theoretical value.

Shown in Fig. 6b are results for glycerol aqueous solutions recorded at room temperature and $0{ }^{\circ} \mathrm{C}$. The overlap in the two data sets indicates that the change in bead speed upon cooling the flow-cell to $0^{\circ} \mathrm{C}$ can be explained by a change in viscosity of the particle. In other words, the bead speed is dependent only on the viscosity of the particle matrix so one calibration curve may be used to determine the viscosities of particles at different temperatures using this technique.

Whether the properties of the organic material have any systematic effect on the relationship between bead speed and viscosity was explored. To do this, the normalized residuals are calculated: normalized residual $=\left(\eta_{\mathrm{p}}-\eta_{1}\right) / \eta_{\mathrm{p}}$, where $\eta_{\mathrm{p}}$ and $\eta_{1}$ are the predicted viscosities using the calibration curve in Fig. 6 and the literature viscosities of the standard solutions, respectively. In Fig. 7, these normalized residuals are plotted vs. O:C (Fig. 7a), molecular weight (Fig. 7b), surface tension (Fig. 7c) and contact angle between the particle and the hydrophobic glass or Teflon substrate (Fig. 7d). If these physical parameters influence the viscosity measurements, systematic positive or negative values or a trend in the residuals is expected. See Supplement and Table S3 for the surface tension values used to generate Fig. 7c. No clear trend is discernible in Fig. 7a-d, suggesting that neither O:C ratio, molecular weight of the organic, surface tension, nor contact angle influences the bead speed vs. viscosity relationship over the ranges studied herein. In order to rule out any contribution to a change in bead speed due to heating by the incandescent light source on the microscope, the bead speed in both glycerol and olive oil particles $(<0.5 \% \mathrm{RH})$ was determined at a variety of lamp powers. The change in bead speed with a change in light intensity was less than the uncertainty in the measurements suggesting heating of the particle by the incandescent light source had negligible effect on the speed of the beads inside the particle matrix even in olive oil samples where visible light absorption is apparent by its yellow color. The bead concentration was maintained so that they constituted much less than $1 \%$ (typically $0.01-$ $0.1 \%$ ) of the total particle volume and the bead speed was independent of bead concentration in this regime. See Fig. 8a for bead speed vs. light intensity and Fig. $8 \mathrm{~b}$ for bead speed vs. bead concentration.

\subsection{Predictions of viscosity of complex, multicomponent particles using calibration data}

To display the utility of this technique for measuring the viscosities of complex particles, the bead speeds in $30-50 \mu \mathrm{m}$ virgin olive oil particles were used along with the calibration curve shown in Fig. 6a to determine the viscosity of the olive oil particles. Like in the measurement of bead speeds for the standard particles, the average bead speed of many (5) beads in multiple (3) particles was determined.

The resulting viscosity of the olive oil particles at room temperature was $0.11(+0.09 /-0.05)$ Pas where the reported error is calculated from the $95 \%$ prediction intervals from the calibration curve in Fig. 6a. This value is in good agreement with previous measurements of the viscosity of virgin olive oils: Coupland and McClements (1997) measured the viscosity of olive oil to be $0.092 \mathrm{Pas}$ at $20^{\circ} \mathrm{C}$ and 

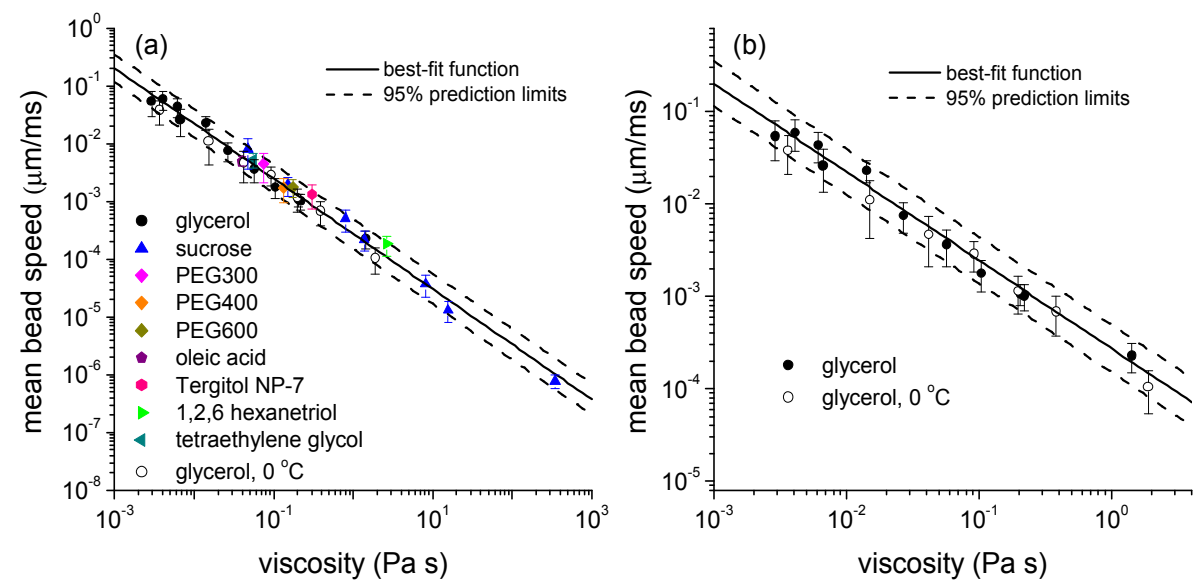

Fig. 6. (a) Average bead speed $( \pm 1 \sigma)$ vs. viscosity for the standard compounds listed in Table 1. (b) Average bead speed ( $\pm 1 \sigma)$ vs. viscosity for aqueous solutions of glycerol at $0^{\circ} \mathrm{C}$ and room temperature in order to display the effect of temperature on the bead speed vs. viscosity results. A calibration line was fit to all of the standard mean bead speed data from the standard compounds. Unless indicated in the figure legend all data correspond to room temperature $\left(20-21.5^{\circ} \mathrm{C}\right)$. Polyethylene glycols with average molecular weights of 300 , 400 , and $600 \mathrm{~g} \mathrm{~mol}^{-1}$ are abbreviated as PEG300, PEG400, and PEG600, respectively.
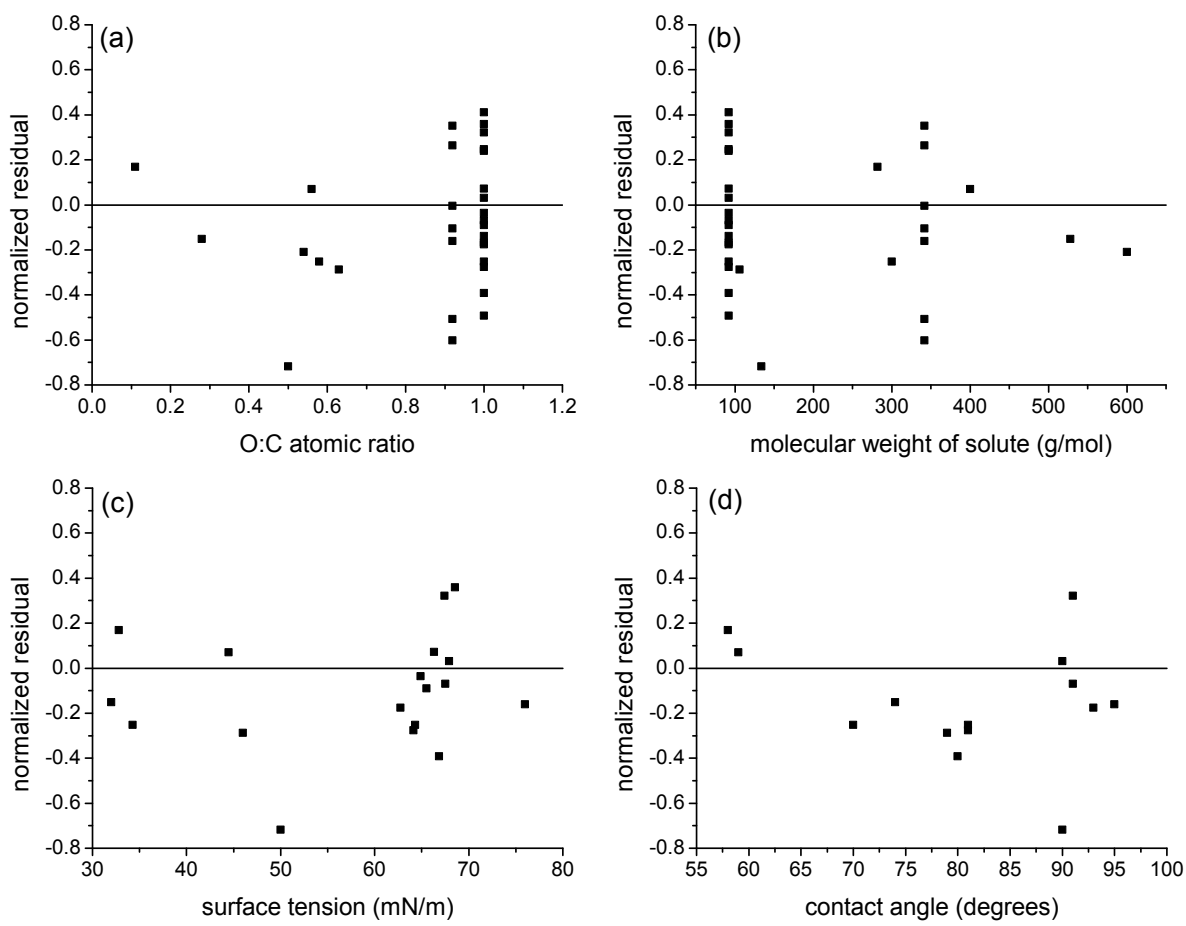

Fig. 7. Normalized residuals from the data presented in Fig. 6, plotted as a function of (a) O:C atomic ratio, (b) molecular weight of solute, (c) surface tension and (d) contact angle.

Fasina et al. (2006) measured the viscosity of olive oil to be $0.087 \mathrm{Pas}$ at $20^{\circ} \mathrm{C}$. The viscosity of the same sample of virgin olive oil as used in the bead movement technique was measured using a conventional rotational viscometer (see Supplement). The viscosity value obtained with the viscometer was $0.097( \pm 0.006)$ Pas, in excellent agreement with the viscosity obtained with the bead technique.
Although nine different organic compounds and some aqueous solutions thereof were used to construct the bead speed vs. viscosity calibration curve in Fig. 6a, it should be noted that much fewer calibration standards are needed to construct a calibration plot. For instance, choosing the room temperature sucrose and glycerol bead speed vs. viscosity data due to the wide viscosity range covered by these 

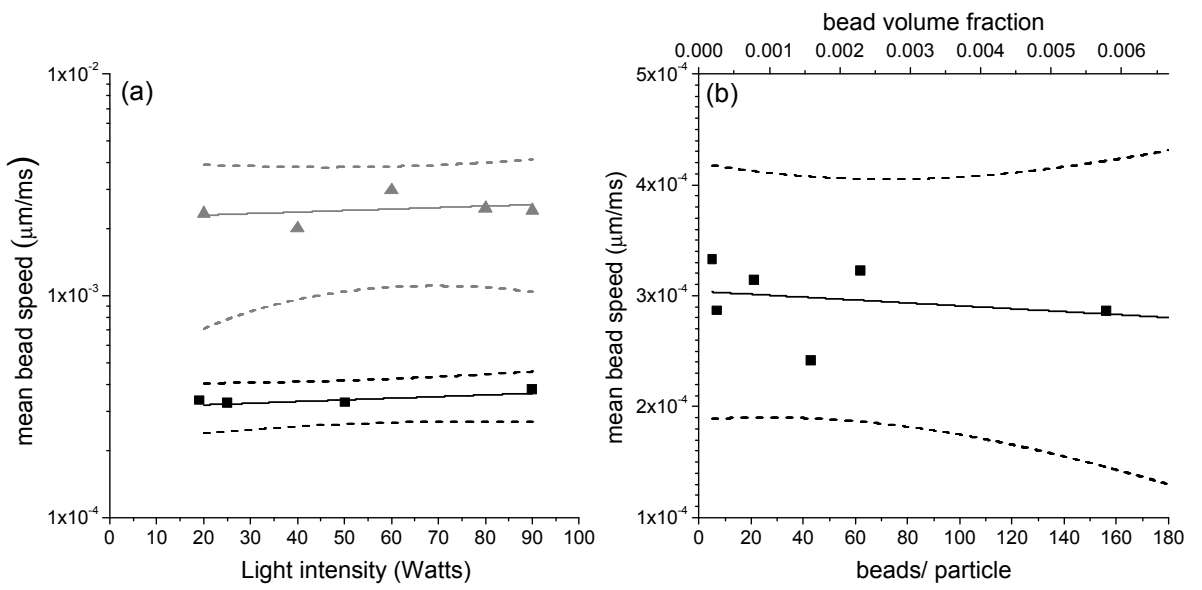

Fig. 8. (a) Mean melamine bead speed vs. light intensity of the halogen light source on the microscope in particles composed of $\sim 100 \mathrm{wt} \%$ glycerol (black squares) and $\sim 100 \mathrm{wt} \%$ olive oil (grey triangles) at room temperature, (b) Mean melamine bead speed vs. number of beads/particle or bead volume fraction in particles composed of $\sim 100 \mathrm{wt} \%$ glycerol. In (a) and (b), the solid lines represent the best fit functions and the dashed lines represent the upper and lower $95 \%$ prediction intervals.

solutions, the resulting viscosity of the complex particles of olive oil was calculated to be $0.11(+0.09 /-0.05)$ Pas, equivalent to the viscosity determined using all of the standard solutions above.

\subsection{Implications for environmental chamber samples}

Above, the rate of internal circulation was shown to be a function of particle viscosity but independent of the particle material for organic and organic-water samples, with O:C values ranging from $0.1-1.0$, surface tensions values ranging from $32-75 \mathrm{mN} \mathrm{m}^{-1}$, and molecular weights ranging from $92-600 \mathrm{~g} \mathrm{~mol}^{-1}$ and the utility of this technique was displayed by determining the viscosity of a complex mixture, virgin olive oil. Consequently, this technique should be well suited for studying the viscosity of many types of secondary organic aerosol particles collected in environmental chambers. For example, typical average O:C ratios of secondary organic particles from environmental chambers are in the range of 0.3-0.6 (Chen et al., 2011; Nguyen et al., 2010; Shilling et al., 2009; Walser et al., 2008). While the surface tensions of secondary organic particles collected in environmental chambers are largely unknown in the subsaturated $\mathrm{RH}$ regime, $\alpha$-pinene secondary organic particles generated in environmental chambers are expected to have surface tensions of $40-75 \mathrm{mN} \mathrm{m}^{-1}$ assuming the surface tension at subsaturated RH is well approximated by an aqueous mixture of pinonic acid, pinic acid, and pinonaldehyde (Huff Hartz et al., 2006; Hyvärinen et al., 2006; Tuckermann and Cammenga, 2004). The molecular weights and structures of particulate secondary organic material formed in environmental chambers vary widely with precursor and oxidant identities as well as with reaction conditions and reaction time; however, for a variety of systems, products with molecular weights $<600 \mathrm{~g} \mathrm{~mol}^{-1}$ make up a significant portion to a majority of the particle mass (Gao et al., 2004; Kalberer et al., 2004; Hamilton et al., 2011; Nguyen et al., 2010, 2011).

The ability to control the relative humidity and temperature of the sample cell allows the viscosity of particles to be measured under atmospherically relevant conditions. Since water may act as a plasticizer in atmospheric particles (Koop et al., 2011; Mikhailov et al., 2009), understanding how the viscosity of particles changes with relative humidity (and thus equilibrium water content) is important in understanding the importance of particle viscosity in atmospheric processes.

\subsection{Advantages and disadvantages of bead technique}

The bead technique currently suffers from fairly poor accuracy with average upper and lower $95 \%$ prediction intervals of $+184 \%$ and $-55 \%$ of the measured viscosity. Because the bead technique is a relative technique relying on the known viscosities of standards, the accuracy may be improved by utilizing certified viscosity standards for the calibration curve construction. However, one of the purposes of this study was to ensure the technique was reliable under changing relative humidity conditions and to use viscosity standards with a wide variety of O:C values, surface tensions, molecular weights, and contact angles in order to show that the technique is applicable to environmental chamber particle samples and this detailed chemical information is often not available for certified viscosity standards.

Some experimental restrictions are also worth noting. First, the contact angle of the particle with the substrate must be large enough so that free movement of beads through the particle may occur. The contact angles of the particles used herein were between $58-95^{\circ}$. Secondly, at viscosities 
$>1000$ Pas, the beads no longer move on a reasonable experimental timescale $<0.2 \mu \mathrm{m} / 10 \mathrm{~min}$ and thus this technique is currently limited to studying the viscosities of relatively fluid particles (i.e. $10^{-3}<\eta<10^{3} \mathrm{Pas}$ ). While this is considered a wide range of viscosities compared to existing microviscometry techniques (Han et al., 2007; Lin et al., 2007; Srivastava et al., 2005; Srivastava and Burns, 2006; Silber-Li et al., 2004), it should be noted that secondary organic matter from chamber oxidation of pinene may potentially range from the viscosity of water $\left(10^{-3} \mathrm{Pas}\right)$ at $100 \% \mathrm{RH}$ to the viscosity of glasses $\left(\geq 10^{12} \mathrm{Pas}\right)$ under dry conditions at or near room temperature (Koop et al., 2011).

There are several advantages of the bead technique for measuring sample viscosities. First, the amount of sample needed to prepare the supermicron particles is $<1 \mathrm{mg}$. In practice, only the material in a single particle (on the order of $10 \mathrm{~s}$ of picoliters) is needed to perform a viscosity measurement with this technique. However, in order to generate the particles with the technique described above, on the order of one or more milligrams (or microliters) of sample is required. Also, the experiment is simple, inexpensive and requires only a microscope equipped with an objective of sufficient magnification to detect the beads in the particle matrix and a gas flow to initiate mixing within the particle. Additionally, inherent in the instrumental design is the ability to have real-time control over the relative humidity and thus the water content of the sample particles, an important attribute for measuring the viscosities of particles under atmospherically relevant conditions.

\section{Conclusions}

A new viscosity measurement technique is developed. Using particles of known viscosity, a relationship between the rate of internal circulation and the particle viscosity is determined. The dependence of this relationship on particle properties such as $\mathrm{O}: \mathrm{C}$ ratio, surface tension, molecular weight, and contact angle is explored. We display the utility of this technique for determining the viscosity of complex, multicomponent particles by determining the viscosity of olive oil particles. The viscosity obtained with this technique is in excellent agreement with literature values and with rotational viscometer results. The applicability of this technique for studying environmental chamber samples is discussed in detail. While the focus of this paper is the establishment of the viscosity measurement technique, future work will focus on viscosity measurements of secondary organic particulate matter from environmental chamber experiments (in preparation) and extending the applicability of this technique to atmospheric samples, which also contain a significant inorganic fraction.

\section{Supplementary material related to this article is available online at: http://www.atmos-chem-phys.net/13/ 791/2013/acp-13-791-2013-supplement.zip.}

Acknowledgements. This research was supported by the National Sciences and Engineering Research Council of Canada and the Canadian Foundation for Innovation. The authors thank Dan Cziczo for helpful discussions and Leopoldo Gutierrez for viscometer training and use.

Edited by: T. Koop

\section{References}

Abdel-Alim, A. H. and Hamielec, A. E.: Theoretical and experimental investigation of the effect of internal circulation on the drag of spherical droplets falling at terminal velocity in liquid media, Ind. Eng. Chem. Fundam., 14, 308-312, doi:10.1021/i160056a004, 1975.

Ahmed, N., Nino, D. F., and Moy, V. T.: Measurement of solution viscosity by atomic force microscopy, Rev. Sci. Instrum., 72, 2731-2734, doi:10.1063/1.1368856, 2001.

Aldrich Chemical Company: 1,2,6-hexanetriol technical bulletin AL-128, available at: http://www.sigmaaldrich.com/etc/ medialib/docs/Aldrich/Bulletin/al_techbull_al128.Par.0001.File. tmp/al_techbull_al0128.pdf (last access: 27 July 2012), 1996.

Bergaud, C. and Nicu, L.: Viscosity measurements based on experimental investigations of composite cantilever beam eigenfrequencies in viscous media, Rev. Sci. Instrum., 71, 2487-2491, doi:10.1063/1.1150640, 2000.

Bodsworth, A., Zobrist, B., and Bertram, A. K.: Inhibition of efflorescence in mixed organic-inorganic particles at temperatures less than 250 K, Phys. Chem. Chem. Phys., 12, 12259-12266, doi:10.1039/C0CP00572J, 2010.

Bones, D. L., Reid, J. P., Lienhard, D. M., and Krieger, U. K.: Comparing the mechanism of water condensation and evaporation in glassy aerosol, Proc. Natl. Acad. Sci. USA, 109, 11613-11618, doi:10.1073/pnas.1200691109, 2012.

Cappa, C. D. and Wilson, K. R.: Evolution of organic aerosol mass spectra upon heating: implications for OA phase and partitioning behavior, Atmos. Chem. Phys., 11, 1895-1911, doi:10.5194/acp11-1895-2011, 2011.

Chen, Q., Liu, Y., Donahue, N. M., Shilling, J. E., and Martin, S. T.: Particle-phase chemistry of secondary organic material: modeled compared to measured O:C and $\mathrm{H}: \mathrm{C}$ elemental ratios provide constraints, Environ. Sci. Technol., 45, 4763-4770, doi:10.1021/es104398s, 2011.

Coupland, J. N. and McClements, D. J.: Physical properties of liquid edible oils, J. Am. Oil Chem. Soc., 74, 1559-1564, doi:10.1007/s11746-997-0077-1, 1997.

Dow Chemical Company: Tergitol NP-7 surfactant technical data sheet, available at: http://msdssearch.dow.com/ PublishedLiteratureDOWCOM/dh_00ae/0901b803800ae909. pdf?filepath=surfactants/pdfs/noreg/119-01915.pdf\&fromPage= GetDoc (last access: 12 August 2012), 2004.

Dow Chemical Company: Tetraethylene Glycol Application Note, available at: 
http://msdssearch.dow.com/PublishedLiteratureDOWCOM/ dh_007e/0901b8038007e5a5.pdf?filepath=ethyleneglycol/pdfs/ noreg/612-00005.pdf \&fromPage=GetDoc (last access: 12 August 2012), 2007.

Fasina, O. O., Hallman, H., Craig-Schmidt, M., and Clements, C.: Predicting temperature-dependence viscosity of vegetable oils from fatty acid composition, J. Am. Oil Chem. Soc., 83, 899903, doi:10.1007/s11746-006-5044-8, 2006.

Gao, S., Keywood, M., Ng, N. L., Surratt, J., Varutbangkul, V., Bahreini, R., Flagan, R. C., and Seinfeld, J. H.: Low-molecularweight and oligomeric components in secondary organic aerosol from the ozonolysis of cycloalkenes and $\alpha$-Pinene, J. Phys. Chem. A, 108, 10147-10164, doi:10.1021/jp047466e, 2004.

Garner, F. H. and Haycock, P. J.: Circulation in liquid drops, Proc. R. Soc. A., 252, 457-475, doi:10.1098/rspa.1959.0166, 1959.

George, I. J. and Abbatt, J. P. D.: Heterogeneous oxidation of atmospheric aerosol particles by gas-phase radicals., Nat. Chem., 2, 713-722, doi:10.1038/nchem.806, 2010.

Hadamard, J.: Mouvement permanent lent d'une sphere liquide et visqueuse dans un liquide visqueux, C. R. Acad. Sci., 152, 17351738, 1911.

Hallquist, M., Wenger, J. C., Baltensperger, U., Rudich, Y., Simpson, D., Claeys, M., Dommen, J., Donahue, N. M., George, C., Goldstein, A. H., Hamilton, J. F., Herrmann, H., Hoffmann, T., Iinuma, Y., Jang, M., Jenkin, M. E., Jimenez, J. L., KiendlerScharr, A., Maenhaut, W., McFiggans, G., Mentel, Th. F., Monod, A., Prévôt, A. S. H., Seinfeld, J. H., Surratt, J. D., Szmigielski, R., and Wildt, J.: The formation, properties and impact of secondary organic aerosol: current and emerging issues, Atmos. Chem. Phys., 9, 5155-5236, doi:10.5194/acp-9-51552009, 2009.

Hamilton, J. F., Rami Alfarra, M., Wyche, K. P., Ward, M. W., Lewis, A. C., McFiggans, G. B., Good, N., Monks, P. S., Carr, T., White, I. R., and Purvis, R. M.: Investigating the use of secondary organic aerosol as seed particles in simulation chamber experiments, Atmos. Chem. Phys., 11, 5917-5929, doi:10.5194/acp11-5917-2011, 2011.

Han, Z., Tang, X., and Zheng, B.: A PDMS viscometer for microliter Newtonian fluid, J. Micromech. Microeng., 17, 1828-1834, doi:10.1088/0960-1317/17/9/011, 2007.

Hess, S. T., Huang, S., Heikal, A. A., and Webb, W. W.: Biological and chemical applications of fluorescence correlation spectroscopy : a review, Biochemistry, 41, 697-705, doi:10.1021/bi0118512, 2002.

Heymes, F., Manno-Demoustier, P., Charbit, F., Fanlo, J. L., and Moulin, P.: A new efficient absorption liquid to treat exhaust air loaded with toluene, Chem. Eng. J., 115, 225-231, doi:10.1016/j.cej.2005.10.011, 2006.

Huff Hartz, K. E., Tischuk, J. E., Chan, M. N., Chan, C. K., Donahue, N. M., and Pandis, S. N.: Cloud condensation nuclei activation of limited solubility organic aerosol, Atmos. Environ., 40, 605-617, doi:10.1016/j.atmosenv.2005.09.076, 2006.

Hyvärinen, A.-P., Lihavainen, H., Gaman, A., Vairila, L., Ojala, H., Kulmala, M., and Viisanen, Y.: Surface tensions and densities of oxalic, malonic, succinic, maleic, malic, and cis-pinonic acids, J. Chem. Eng. Data, 51, 255-260, doi:10.1021/je050366x, 2006.

IPCC: IPCC Fourth Assessment Report: Climate Change 2007: The Physical Science Basis: Contribution of Working Group I to the Fourth Assessment Report of the Intergovernmental Panel on Climate Change, edited by: Solomon, S., Qin, D., Manning, M., Chen, Z., Marquis, M., Averyt, K. B., Tignor, M., and Miller, H. L., Cambridge University Press, Cambridge University Press, Cambridge, UK and New York, NY, USA, 996 pp., 2007.

Jimenez, J. L., Canagaratna, M. R., Donahue, N. M., Prevot, A. S. H., Zhang, Q., Kroll, J. H., DeCarlo, P. F., Allan, J. D., Coe, H., Ng, N. L., Aiken, A. C., Docherty, K. S., Ulbrich, I. M., Grieshop, A. P., Robinson, A. L., Duplissy, J., Smith, J. D., Wilson, K. R., Lanz, V. A., Hueglin, C., Sun, Y. L., Tian, J., Laaksonen, A., Raatikainen, T., Rautiainen, J., Vaattovaara, P., Ehn, M., Kulmala, M., Tomlinson, J. M., Collins, D. R., Cubison, M. J. E., Dunlea, J., Huffman, J. A., Onasch, T. B., Alfarra, M. R., Williams, P. I., Bower, K., Kondo, Y., Schneider, J., Drewnick, F., Borrmann, S., Weimer, S., Demerjian, K., Salcedo, D., Cottrell, L., Griffin, R., Takami, A., Miyoshi, T., Hatakeyama, S., Shimono, A., Sun, J. Y., Zhang, Y. M., Dzepina, K., Kimmel, J. R., Sueper, D., Jayne, J. T., Herndon, S. C., Trimborn, A. M., Williams, L. R., Wood, E. C., Middlebrook, A. M., Kolb, C. E., Baltensperger, U., and Worsnop, D. R.: Evolution of organic aerosols in the atmosphere, Science, 326, 1525-1529, doi:10.1126/science.1180353, 2009.

Kalberer, M., Paulsen, D., Sax, M., Steinbacher, M., Dommen, J., Prevot, A. S. H., Fisseha, R., Weingartner, E., Frankevich, V., Zenobi, R., and Baltensperger, U.: Identification of polymers as major components of atmospheric organic aerosols, Science, 303, 1659-1662, doi:10.1126/science.1092185, 2004.

Kanakidou, M., Seinfeld, J. H., Pandis, S. N., Barnes, I., Dentener, F. J., Facchini, M. C., Van Dingenen, R., Ervens, B., Nenes, A., Nielsen, C. J., Swietlicki, E., Putaud, J. P., Balkanski, Y., Fuzzi, S., Horth, J., Moortgat, G. K., Winterhalter, R., Myhre, C. E. L., Tsigaridis, K., Vignati, E., Stephanou, E. G., and Wilson, J.: Organic aerosol and global climate modelling: a review, Atmos. Chem. Phys., 5, 1053-1123, doi:10.5194/acp-51053-2005, 2005.

Katrib, Y., Biskos, G., Buseck, P. R., Davidovits, P., Jayne, J. T., Mochida, M., Wise, M. E., Worsnop, D. R., and Martin, S. T.: Ozonolysis of mixed oleic-acid/stearic-acid particles: reaction kinetics and chemical morphology, J. Phys. Chem. A, 109, 10910-10919, doi:10.1021/jp054714d, 2005.

Knopf, D. A., Anthony, L. M., and Bertram, A. K.: Reactive uptake of $\mathrm{O}_{3}$ by multicomponent and multiphase mixtures containing oleic acid, J. Phys. Chem. A, 109, 5579-5589, doi:10.1021/jp0512513, 2005.

Koop, T., Bookhold, J., Shiraiwa, M., and Pöschl, U.: Glass transition and phase state of organic compounds: dependency on molecular properties and implications for secondary organic aerosols in the atmosphere., Phys. Chem. Chem. Phys., 13, 19238-19255, doi:10.1039/c1cp22617g, 2011.

LeClair, B. P., Hamielec, A. E., Pruppacher, H. R., and Hall, W. D.: A theoretical and experimental study of the internal circulation in water drops falling at terminal velocity in air, J. Atmos. Sci., 29, 728-740, doi:10.1175/15200469(1972)029<0728:ATAESO > 2.0.CO;2, 1972.

Lin, Y.-Y., Lin, C.-W., Yang, L.-J., and Wang, A.-B.: Microviscometer based on electrowetting on dielectric, Electrochim. Acta, 52, 2876-2883, doi:10.1016/j.electacta.2006.10.025, 2007. 
Malik, R., Burch, D., Bazant, M., and Ceder, G.: Particle size dependence of the ionic diffusivity, Nano. Lett., 10, 4123-4127, doi:10.1021/nl1023595, 2010.

McDonald, J. E.: The shape and aerodynamics of large raindrops, J. Meteorol., 11, 478-494, doi:10.1175/15200469(1954)011<0478:TSAAOL > 2.0.CO;2, 1954.

Mikhailov, E., Vlasenko, S., Martin, S. T., Koop, T., and Pöschl, U.: Amorphous and crystalline aerosol particles interacting with water vapor: conceptual framework and experimental evidence for restructuring, phase transitions and kinetic limitations, Atmos. Chem. Phys., 9, 9491-9522, doi:10.5194/acp-9-9491-2009, 2009.

Milne-Thomson, L. M.: Theoretical Hydrodynamics, Macmillan Publishing Group, London, UK, 743 pp., 1968.

Moumen, N., Subramanian, R. S., and McLaughlin, J. B.: Experiments on the motion of drops on a horizontal solid surface due to a wettability gradient, Langmuir, 22, 2682-2690, doi:10.1021/1a053060x, 2006.

Murray, B. J.: Inhibition of ice crystallisation in highly viscous aqueous organic acid droplets, Atmos. Chem. Phys., 8, 54235433, doi:10.5194/acp-8-5423-2008, 2008.

Murray, B. J., Wilson, T. W., Dobbie, S., Cui, Z., Al-Jumur, S., Möhler, O., Schnaiter, M., Wagner, R., Benz, S., Niemand, M., Saathoff, H., Ebert, V., Wagner, S., and Kärcher, B.: Heterogeneous nucleation of ice particles on glassy aerosols under cirrus conditions, Nat. Geosci., 3, 233-237, doi:10.1038/ngeo817, 2010.

Murray, B. J., Haddrell, A. E., Peppe, S., Davies, J. F., Reid, J. P., O'Sullivan, D., Price, H. C., Kumar, R., Saunders, R. W., Plane, J. M. C., Umo, N. S., and Wilson, T. W.: Glass formation and unusual hygroscopic growth of iodic acid solution droplets with relevance for iodine mediated particle formation in the marine boundary layer, Atmos. Chem. Phys., 12, 8575-8587, doi:10.5194/acp-12-8575-2012, 2012.

Nagy, J. A., Herzberg, K. T., Masse, E. M., Zientara, G. P., and Dvorak, H. F.: Exchange of macromolecules between plasma and peritoneal cavity in ascites tumor-bearing, normal, and serotonininjected mice, Cancer Res., 49, 5448-5458, 1989.

Nguyen, T. B., Bateman, A. P., Bones, D. L., Nizkorodov, S. A., Laskin, J., and Laskin, A.: High-resolution mass spectrometry analysis of secondary organic aerosol generated by ozonolysis of isoprene, Atmos. Environ., 44, 1032-1042, doi:10.1016/j.atmosenv.2009.12.019, 2010.

Nguyen, T. B., Roach, P. J., Laskin, J., Laskin, A., and Nizkorodov, S. A.: Effect of humidity on the composition of isoprene photooxidation secondary organic aerosol, Atmos. Chem. Phys., 11, 6931-6944, doi:10.5194/acp-11-6931-2011, 2011.

Noureddini, H., Teoh, B. C., and Davis Clements, L.: Viscosities of vegetable oils and fatty acids, J. Am. Oil Chem. Soc., 69, 11891191, doi:10.1007/BF02637678, 1992.

Parsons, M. T., Mak, J., Lipetz, S. R., and Bertram, A. K.: Deliquescence of malonic, succinic, glutaric, and adipic acid particles, J. Geophys. Res., 109, D06212, doi:10.1029/2003JD004075, 2004.

Perraud, V., Bruns, E. A., Ezell, M. J., Johnson, S. N., Yu, Y., Alexander, M. L., Zelenyuk, A., Imre, D., Chang, W. L., Dabdub, D., Pankow, J. F., and Finlayson-Pitts, B. J.: Nonequilibrium atmospheric secondary organic aerosol formation and growth., Proc. Natl. Acad. Sci. USA, 109, 2836-2841, doi:10.1073/pnas.1119909109, 2012.
Pipe, C. J. and McKinley, G. H.: Microfluidic rheometry, Mech. Res. Commun., 36, 110-120, doi:10.1016/j.mechrescom.2008.08.009,2009.

Pöschl, U.: Atmospheric aerosols: composition, transformation, climate and health effects., Angew. Chem. Int. Ed., 44, 7520-7540, doi:10.1002/anie.200501122, 2005.

Pruppacher, H. R. and Beard, K. V.: A wind tunnel investigation of the internal circulation and shape of water drops falling at terminal velocity in air, Q. J. Roy. Meteor. Soc., 96, 247-256, doi:10.1002/qj.49709640807, 1970.

Reist, P. C.: Introduction to aerosol science, Macmillan Publishing Company, New York, NY, USA, 1984.

Reits, E. A. and Neefjes, J. J.: From fixed to FRAP: measuring protein mobility and activity in living cells., Nat. Cell Biol., 3, 145147, doi:10.1038/35078615, 2001.

Renbaum, L. H. and Smith, G. D.: The importance of phase in the radical-initiated oxidation of model organic aerosols: reactions of solid and liquid brassidic acid particles, Phys. Chem. Chem. Phys., 11, 2441-2451, doi:10.1039/b816799k, 2009.

Rossow, M. J., Sasaki, J. M., Digman, M. A. and Gratton, E.: Raster image correlation spectroscopy in live cells., Nat. Protoc., 5, 1761-1774, doi:10.1038/nprot.2010.122, 2010.

Rudich, Y., Donahue, N. M., and Mentel, T. F.: Aging of organic aerosol: Bridging the gap between laboratory and field studies, Annu. Rev. Phys. Chem., 58, 321-352, doi:10.1146/annurev.physchem.58.032806.104432, 2007.

Saukko, E., Lambe, A. T., Massoli, P., Koop, T., Wright, J. P., Croasdale, D. R., Pedernera, D. A., Onasch, T. B., Laaksonen, A., Davidovits, P., Worsnop, D. R., and Virtanen, A.: Humiditydependent phase state of SOA particles from biogenic and anthropogenic precursors, Atmos. Chem. Phys., 12, 7517-7529, doi:10.5194/acp-12-7517-2012, 2012.

Shilling, J. E., Chen, Q., King, S. M., Rosenoern, T., Kroll, J. H., Worsnop, D. R., DeCarlo, P. F., Aiken, A. C., Sueper, D., Jimenez, J. L., and Martin, S. T.: Loading-dependent elemental composition of a-pinene SOA particles, Atmos. Chem. Phys., 9, 771-782, doi:10.5194/acp-9-771-2009, 2009.

Shiraiwa, M., Ammann, M., Koop, T., and Pöschl, U.: Gas uptake and chemical aging of semisolid organic aerosol particles., Proc. Natl. Acad. Sci. USA, 108, 11003-11008, doi:10.1073/pnas.1103045108, 2011.

Silber-Li, Z. H., Tan, Y. P., and Weng, P. F.: A microtube viscometer with a thermostat, Exp. Fluids, 36, 586-592, doi:10.1007/s00348-003-0730-x, 2004.

Song, H., Tice, J. D., and Ismagilov, R. F.: A microfluidic system for controlling reaction networks in time, Angew. Chem. Int. Ed., 42, 767-772, doi:10.1002/anie.200390203, 2003.

Spells, K.: A study of circulation patterns within liquid drops moving through a liquid, Proc. Phys. Soc. B, 65, 541-546, doi:10.1088/0370-1301/65/7/310, 1952.

Spiller, D. G., Wood, C. D., Rand, D. A., and White, M. R. H.: Measurement of single-cell dynamics, Nature, 465, 736-745, doi:10.1038/nature09232, 2010.

Srivastava, N., Davenport, R. D., and Burns, M. A.: Nanoliter viscometer for analyzing blood plasma and other liquid samples, Anal. Chem., 77, 383-392, doi:10.1021/ac0494681, 2005.

Srivastava, N. and Burns, M. A.: Analysis of non-Newtonian liquids using a microfluidic capillary viscometer, Anal. Chem., 78, 1690-1696, doi:10.1021/ac0518046, 2006. 
Szakáll, M., Diehl, K., Mitra, S. K., and Borrmann, S.: A wind tunnel study on the shape, oscillation, and internal circulation of large raindrops with sizes between 2.5 and $7.5 \mathrm{~mm}$, J. Atmos. Sci., 66, 755-765, doi:10.1175/2008JAS2777.1, 2009.

Tuckermann, R. and Cammenga, H. K.: The surface tension of aqueous solutions of some atmospheric watersoluble organic compounds, Atmos. Environ., 38, 6135-6138, doi:10.1016/j.atmosenv.2004.08.005, 2004.

Vaden, T. D., Imre, D., Beránek, J., Shrivastava, M., and Zelenyuk, A.: Evaporation kinetics and phase of laboratory and ambient secondary organic aerosol., Proc. Natl. Acad. Sci. USA, 108, 2190-2195, doi:10.1073/pnas.1013391108, 2011.

Valeri, D. and Meirelles, A. J. A.: Viscosities of fatty acids, triglycerides, and their binary mixtures, J. Am. Oil Chem. Soc., 74, 1221-1226, doi:10.1007/s11746-997-0048-6, 1997.

Virtanen, A., Joutsensaari, J., Koop, T., Kannosto, J., Yli-Pirilä, P., Leskinen, J., Mäkelä, J. M., Holopainen, J. K., Pöschl, U., Kulmala, M., Worsnop, D. R., and Laaksonen, A.: An amorphous solid state of biogenic secondary organic aerosol particles., Nature, 467, 824-827, doi:10.1038/nature09455, 2010.

Walser, M. L., Desyaterik, Y., Laskin, J., Laskin, A., and Nizkorodov, S. A.: High-resolution mass spectrometric analysis of secondary organic aerosol produced by ozonation of limonene, Phys. Chem. Chem. Phys., 10, 1009-1022, doi:10.1039/B712620D, 2008.
Wang, B., Lambe, A. T., Massoli, P., Onasch, T. B., Davidovits, P., Worsnop, D. R., and Knopf, D. A.: The deposition ice nucleation and immersion freezing potential of amorphous secondary organic aerosol: pathways for ice and mixed-phase cloud formation, J. Geophys. Res., 117, D16209, doi:10.1029/2012jd018063, 2012.

You, Y., Renbaum-Wolff, L., Carreras-Sospedra, M., Hanna, S. J., Hiranuma, N., Kamal, S., Smith, M. L., Zhang, X., Weber, R. J., Shilling, J. E., Dabdub, D., Martin, S. T., and Bertram, A. K.: Images reveal that atmospheric particles can undergo liquid-liquid phase separations., Proc. Natl. Acad. Sci. USA, 109, 1318813193, doi:10.1073/pnas.1206414109, 2012.

Zhang, K., Yang, J., Yu, X., Zhang, J., and Wei, X.: Densities and viscosities for binary mixtures of poly ( ethylene glycol) $400+$ dimethyl sulfoxide and poly (ethylene glycol) $600+$ water at different temperatures, J. Chem. Eng. Data, 56, 3083-3088, doi:10.1021/je200148u, 2011.

Zobrist, B., Marcolli, C., Pedernera, D. A., and Koop, T.: Do atmospheric aerosols form glasses?, Atmos. Chem. Phys., 8, 52215244, doi:10.5194/acp-8-5221-2008, 2008.

Zobrist, B., Soonsin, V., Luo, B. P., Krieger, U. K., Marcolli, C., Peter, T., and Koop, T.: Ultra-slow water diffusion in aqueous sucrose glasses., Phys. Chem. Chem. Phys., 13, 3514-3526, doi:10.1039/c0cp01273d, 2011. 